\title{
Relationship between eggplant seed morphology and germination ${ }^{1}$
}

\author{
Vanessa Neumann Silva ${ }^{2 *}$, Silvio Moure Cicero ${ }^{2}$, Mark Bennett ${ }^{3}$
}

\begin{abstract}
Structural differences such as abnormalities, damage and free spaces in seeds may affect germination. The aim of this study was to study the relationship between eggplant seed morphology and seed germination. Ten seed lots of the eggplant cultivar Embu were evaluated by X-ray image analysis and the germination test. Seed image analysis was performed by Image Pro Plus ${ }^{\circledR}$ software and the whole seed area and free space between the embryo and endosperm were measured. The internal seed area filled by the embryo and endosperm was calculated from the difference between the whole seed and free space areas. Based on these results and visual seed analysis, seeds were classified into three categories and information on germination was obtained for each one. X-ray image analysis provides a perfect view of the internal seed parts and for seed morphology studies. An increase in seed area filled by the endosperm and embryo does not improve seed germination. Mechanical seed damage and deteriorated tissues can adversely affect seed germination.
\end{abstract}

Index terms: X-ray, Solanum melongena L., embryo.

\section{Relação entre a morfologia interna e a germinação de sementes de berinjela}

\begin{abstract}
RESUMO - Diferenças estruturais como anormalidades, danos e áreas livres no interior da semente podem afetar diretamente a germinação. O objetivo deste trabalho foi verificar a relação existente entre a morfologia interna de sementes de berinjela e a germinação. Para tanto, sementes de berinjela, representadas por 10 lotes (cultivar Embu), foram avaliadas por meio do teste de raios $\mathrm{X}$, sendo posteriormente submetidas ao teste de germinação. As imagens das sementes foram analisadas com o software Image Pro Plus ${ }^{\circledR}$ e o espaço livre entre o embrião e o endosperma de cada semente foi mensurado calculando-se o espaço da cavidade interna das sementes ocupado pelo embrião e endosperma, por diferença; com base nestes dados e na análise visual das sementes, foi realizada a classificação das sementes em três categorias e os resultados foram confrontados com os dados de germinação. Conclui-se que a análise de raios $\mathrm{X}$ permite a visualização das partes componentes das sementes de berinjela e, assim, possibilita o estudo da relação entre a morfologia interna e a germinação. A presença de maior área ocupada pelo embrião e endosperma não favoreceu a germinação. Danos mecânicos ou presença de tecidos deteriorados nas sementes podem afetar negativamente a germinação.
\end{abstract}

Termos para indexação: Solanum melongena L., raios X, embrião.

\section{Introduction}

During seed formation, conditions for plant development may be unfavorable. These include temperature extremes,

${ }^{1}$ Submitted on 05/04/2012. Accepted for publication on 07/19/2012.

${ }^{2}$ Departamento de Produção Vegetal, USP/ESALQ, Caixa Postal 9, 13418-900-Piracicaba, SP, Brasil. lack or excess of water and disease attack, among other things, which besides adversely affecting plant metabolism may result in poor seed formation. Thus ripe seeds may show structural differences, including abnormalities, and

${ }^{3}$ Department of Horticulture and Crop Science, The Ohio State University (OSU), 43210-1086-Ohio, USA.

*Corresponding author $<$ vnpel@yahoo.com.br> 
may directly affect germination and vigor, which can be evaluated by analyzing X-ray images.

The X-ray test consists of the X-ray analysis of the internal seed structure by exposing it to a low energy source of X-rays and a photosensitive film. When the X-rays pass through the seeds and reach the film they form an image with different levels of grey. The principle of the technique is defined by the absorption of X-rays in different quantities by the seed tissues due to their structure, composition and density, as well as the radiation exposure time (ISTA, 2004). It is a relatively quick test, standardized by the International Rules for Seed Analysis (ISTA, 2004) and recommended in the Brazilian Rules for Seed Analysis (Brasil, 2009).

Although the X-rays are potentially harmful to seeds, the low dose absorbed during the analysis does not cause genetic mutations or affect seed germination (Simak and Gustafsson, 1953). Therefore, it is nondestructive, allowing physiological tests with seeds and the establishment of cause and effect relationships (Cicero and Banzatto-Junior, 2003).

The X-ray test has been used with various objectives including relating internal morphology to seed germination in tomatoes (Van Der Burg et al., 1994), Lithraea molleoides (Machado and Cicero, 2003), Peltophorum dubium (Oliveira et al., 2003), bell pepper (Dell'Áquilla, 2007; Gagliardi and Marcos-Filho, 2011) and rice (Menezes et al., 2012).

In studying internal seed morphology, one parameter which may be evaluated is embryo size, which can be defined by the degree of development and the free space in the internal seed cavity (Marcos-Filho et al., 2010); this free space was determined for the first time for tomato seeds and includes the free spaces between the embryo and the endosperm or between the seed contents and the tegument, which can occur in different parts of the seed, but normally around the embryo (Liu et al., 1993).

The measurement of the free space inside the seed and the embryo size can be done by analyzing the $\mathrm{X}$-ray images with Image Pro Plus ${ }^{\circledR}$ software. This computer program was used to quantify the free space in bell pepper seeds, when those seeds with free spaces larger than $2.7 \%$ compared to their total area, showed a progressive reduction in normal seedling germination (Dell'Áquilla, 2007). Research done by Gagliardi and Marcos-Filho (2011) gave a similar result for the same species, where the number of abnormal seedlings increased proportionately with the increase in free space; however, the quantification of free space in this study was made visually and this can be subjective.

The objective of this study was to verify the relationship between internal seed morphology and germination in eggplants.

\section{Material and Methods}

The research was done at the Seed Analysis and Image Analysis Laboratories of the Plant Production Department of the Escola Superior de Agricultura "Luiz de Queiroz" of São Paulo University, Piracicaba, São Paulo state and in the Seed Laboratory of Ohio State University, Columbus - Ohio/U.S.A. Ten lots of eggplant seeds (Embu cultivar) were treated with Thiram fungicide and stored in aluminium paper containers, hermetically sealed, in a controlled environment at $20 \pm 1{ }^{\circ} \mathrm{C}$ and $45-50 \%$ relative humidity for 12 months. After storage, the seeds were analyzed with the $\mathrm{X}$-ray test and later subjected to the germination test.

The X-ray test was done with eight replications of 25 seeds, placed on double-faced adhesive tape on a transparent plastic sheet; the seeds were numbered according to their position on the sheet, so they could be identified later. The plastic sheet was placed inside a Faxitron ${ }^{\circledR}$ digital X-ray machine (model MX-20 DC-12) linked to a Core 2 Duo computer $(3.16 \mathrm{GHz}$, 2 GB of memory RAM, 160 GB Hard Disk) and a MultiSync monitor (17 inch LCD1990SX) and submitted to radiation for 20 seconds at $20 \mathrm{kV}$. The images produced were saved in the computer hard disc for later analysis. The seeds were removed from the transparent sheet and transferred to an acrylic tray with individual cells numbered in the same order as they were for the X-ray images.

The germination test was done on a paper towel moistened with distilled water in a ratio equivalent to 2.5 times the weight of the paper. The previously numbered seeds were distributed on two sheets of paper towel (on the upper third of the substrate to allow individual seedling development) and covered with another sheet. The rolls were taken to the germinator at $20-30{ }^{\circ} \mathrm{C}$ and the evaluation was made on the seventh day after sowing. The normal and abnormal seedlings and the dead seeds were removed from the substrate and photographed with a Nikon ${ }^{\circledR}$ model D10 digital camera linked to a computer. The images were saved on the computer hard disc for later analysis.

The images of the X-rayed seeds were analyzed with a version 7.0 Image Pro Plus ${ }^{\circledR}$ (Media Cybernetics ${ }^{\circledR}$, EUA) software to determine the area of the seed and the free space inside the seed and also the ratio between these areas. A calculation was made subtracting the free space area from the total seed area to obtain the area occupied by the embryo and endosperm tissues. The mean value of the 
area of the internal seed cavity occupied by the embryo and endosperm in the 200 seeds sample was also calculated to facilitate analysis as well as the standard deviation of each lot. Based on these results, the seeds were classified into three categories as follows:

a) category 1: seeds with endosperm and embryo areas less than the mean minus one standard deviation; b) category 2: seeds with endosperm and embryo areas between the mean minus one standard deviation and the mean; c) category 3: seeds with an area greater than the mean.

Since few seeds were damaged (poor formation of their parts and/ or deteriorated tissues), it was decided to focus the study on the relationship between the filling of the internal seed cavity and germination and show the isolated cases of damage.

\section{Results and Discussion}

The cavity area of the eggplant seeds occupied by the embryo and endosperm was greater than $88 \%$ for all lots (Table 1), and it can be seen from Figure 1 that for most seeds in all lots, the area occupied by the embryo and endosperm was greater than $97 \%$. Evaluation of internal seed morphology is important both to characterize poorly studied species as well as to evaluate seed quality regarding the physical and physiological attributes (Gomes Junior, 2010).

Table 1. Area (\%) occupied by the embryo and endosperm of eggplant seeds, Embu cultivar, in relation to the total seed area (mean for each lot) and values of the categories used for data analysis.

\begin{tabular}{ccccc}
\hline Lot & $\begin{array}{c}\text { Area } \\
\text { (Embryo + Endosperm) }\end{array}$ & $\begin{array}{c}\text { Standard } \\
\text { Deviation }\end{array}$ & \multicolumn{2}{c}{$\begin{array}{c}\text { Category } \\
\text { (area embryo + endosperm) }\end{array}$} \\
\hline 1 & 97.53 & 1.57 & 1 & \\
2 & 97.70 & 1.84 & & \\
3 & 97.18 & 1.83 & & \\
4 & 97.62 & 1.69 & & \\
5 & 97.97 & 1.38 & & \\
6 & 97.77 & 1.56 & & \\
7 & 97.63 & 1.64 & & \\
8 & 97.87 & 1.60 & & \\
9 & 97.92 & 1.69 & & \\
10 & 97.24 & 1.82 & & \\
\hline Mean & 97.64 & 1.66 & & \\
\hline
\end{tabular}

When the seeds of Tabebuia avellanedae were analyzed with X-rays, it was observed that in most cases, when the embryonic cavity was totally filled with the cotyledon axis and well-formed cotyledons, normal seedlings were produced (Amaral et al., 2011). However, until now, there have been no data on this topic for eggplant seeds in the literature.

Regarding the percentage of seeds in each lot with a greater internal area occupied by the embryo and endosperm, more than $60 \%$ were classified in category 3 in most lots. Examples of seeds with different internal cavity areas occupied by the embryo and endosperm can be seen in Figure 2. When the internal cavity is not completely filled by the embryo and the endosperm or contains less dense tissues, the X-ray analysis produces images with dark areas, because the resistance is not strong enough to block the passage of the X-rays (Gagliardi and Marcos-Filho, 2011).

Another important factor which should be considered when analyzing internal seed morphology is the presence or absence of any damage. In this study, the overall observation was that few of the sample seeds had been damaged. Some examples of seeds with mechanical damage and deteriorated tissues, which affected germination, are shown in Figure 3. In Figure 3A, mechanical damage to the embryo is apparent and caused death of the seed (Figure 3A'). Similarly, it was found that mechanical damage to the embryonic axis of corn seeds affected germination, resulting in abnormal seedlings or dead seeds (Cicero and Banzatto-Junior, 2003). In Figures 3B and $3 \mathrm{C}$, dark areas caused by deterioration of the radicle extremity (Figure 3B) and the cotyledon (Figure 3C) can be seen, and this adversely affected the germination, resulting in seedlings with a root abnormality (Figure 3B') and an abnormal seedling (Figure 3C'). Similar results are described for the seeds of Lithraea molleoides (Machado and Cicero, 2003) and bell pepper (Gagliardi and Marcos-Filho, 2011). 
Lot 1

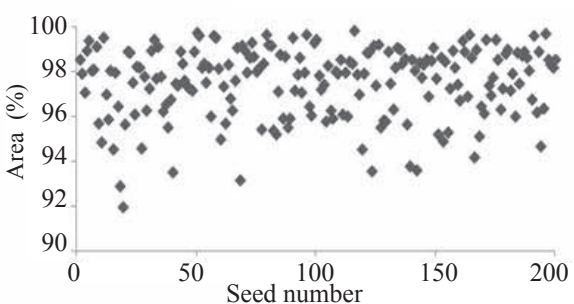

Lot 4

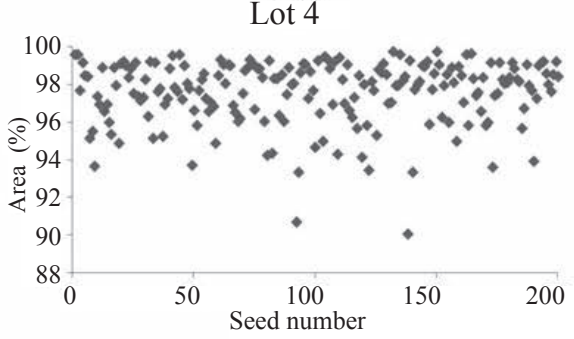

Lot 7

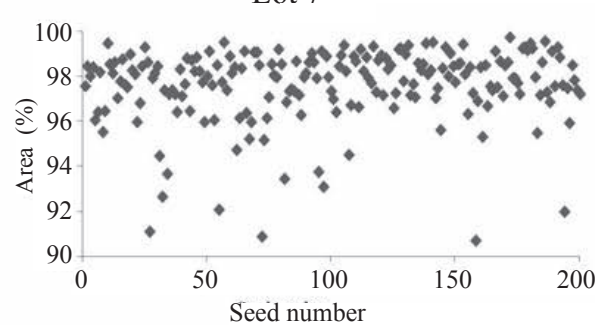

Lot 10

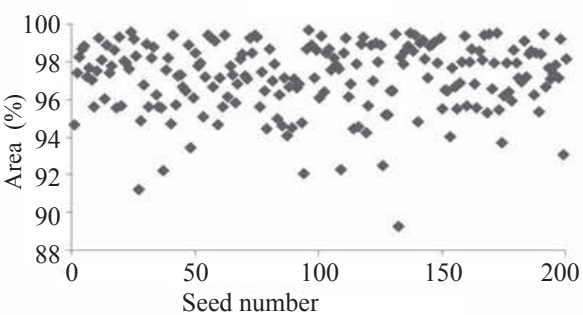

Lot 2

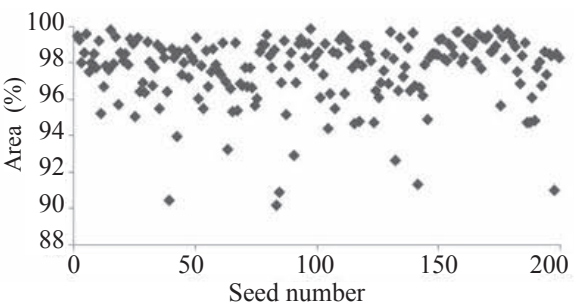

Lot 5

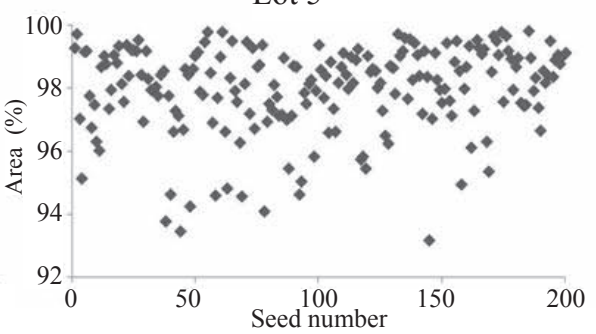

Lot 8
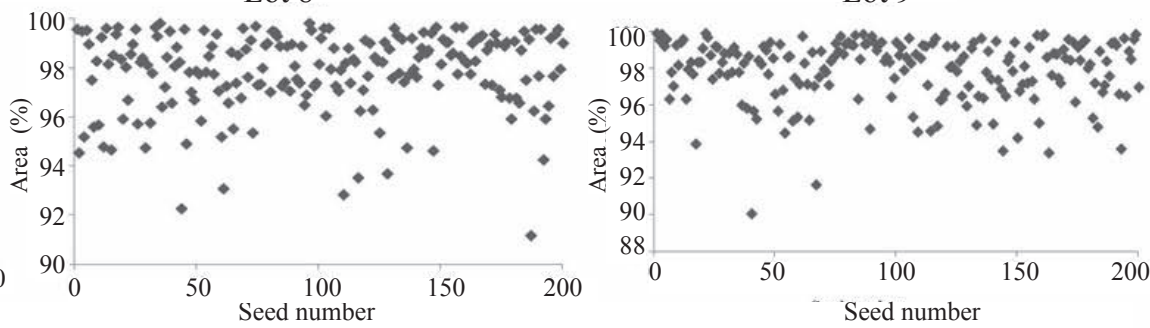

Lot 3

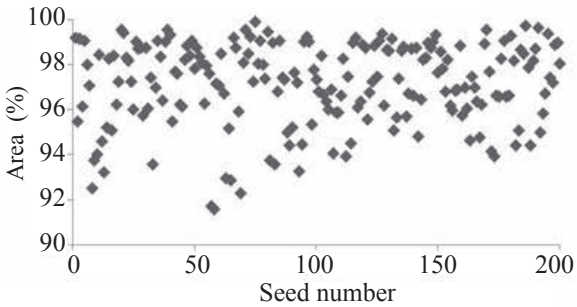

Lot 6

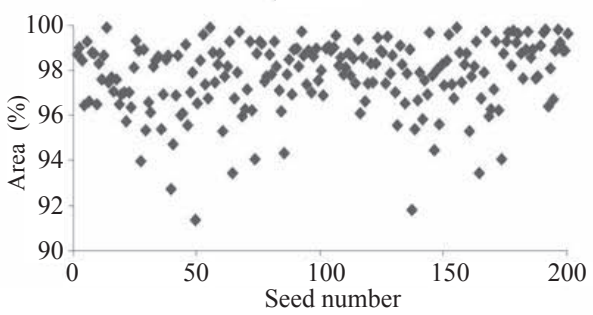

Lot 9

Figure 1. Area (\%) of the internal cavity occupied by the embryo and endosperm of each seed for a sample with 200 individuals, of eggplant, Embu cultivar.

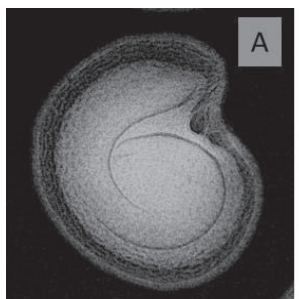

$(<95,98)$

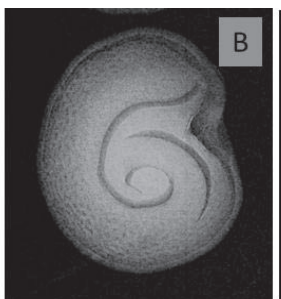

$(95,98-97,64)$

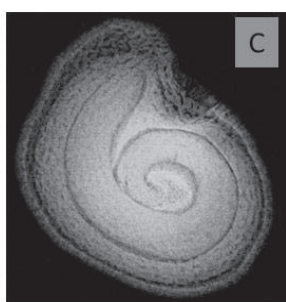

$(>97,64)$

Figure 2. Examples of egg plant seeds with differences in the internal area cavity filled with the embryo and endosperm, category 1 (A), category 2 (B) and category $3(\mathrm{C})$.

From the results shown in Table 2, relating seed morphology to the results of the germination test, a small difference in the germination of seeds from the different morphological categories could be seen, when only seeds from lot 1 with lot larger area of endosperm and embryo produced a higher percentage of normal seedlings.

It is possible that completely formed seeds have a greater probability of producing normal seedlings since their embryos have a greater chance of developing and more storage reserves in the endosperm can favor germination; however, other factors interfere in this process, such as the history of the seeds produced, including production place and time, fruit harvesting, 
fruit storage time before seed extraction, extraction method, type of drying, the packaging used and storage conditions, all of which influence the physiological potential and, therefore, the germinative capacity.

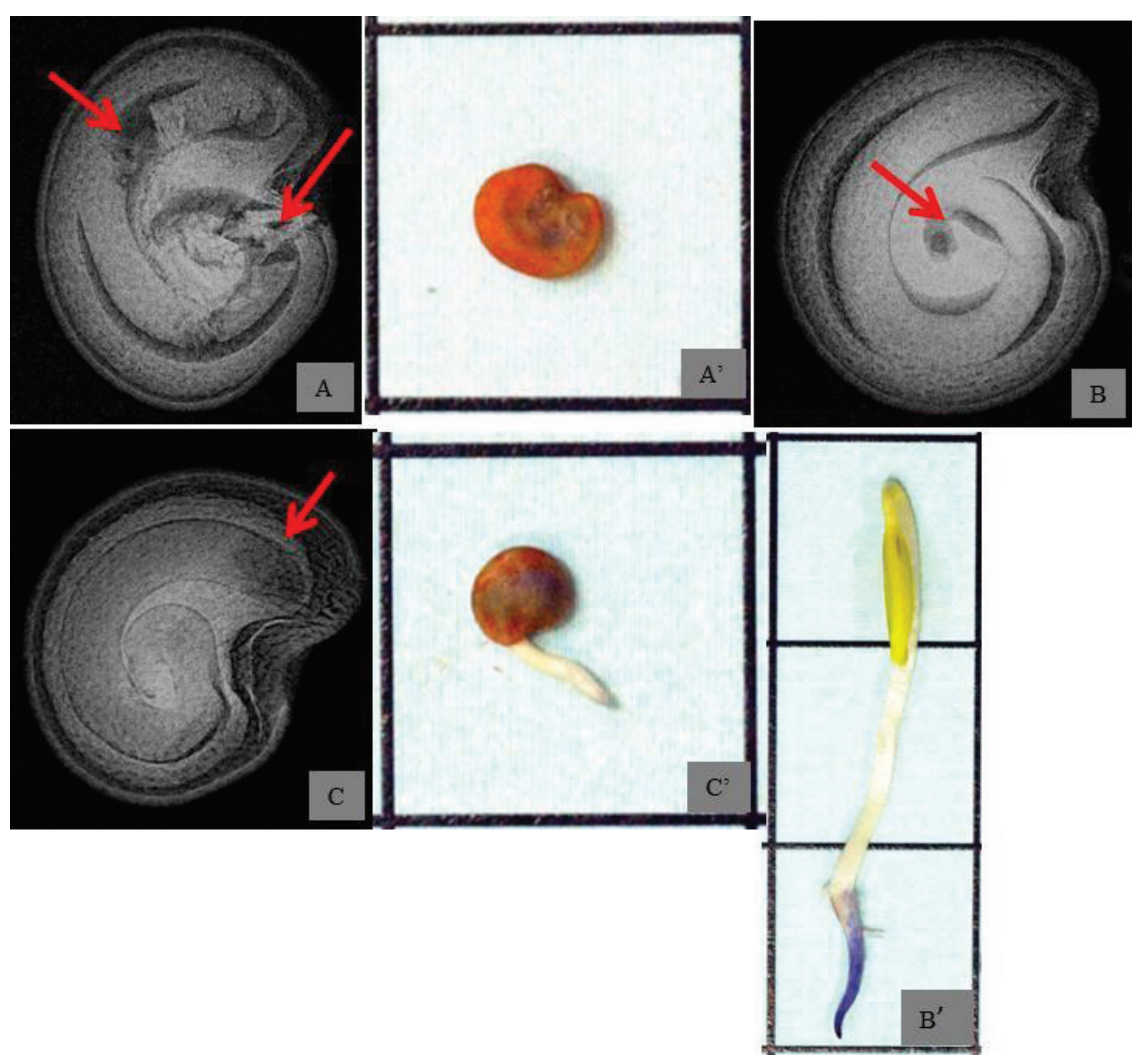

Figure 3. Eggplant seeds, Embu cultivar, showing: deformed seed (A) and deteriorated embryo tissues (B and C) and the respective dead seed (A') and abnormal seedlings (B' and C').

Table 2. Percentage of seeds (S) of each category (C) of internal morphology and normal (NS), abnormal seedlings (AS) and dead seeds (DS) obtained in the germination test for eggplant seeds.

\begin{tabular}{|c|c|c|c|c|c|c|c|c|c|c|c|}
\hline Lot & $\mathrm{C}$ & S (\%) & NS (\%) & AS (\%) & DS (\%) & Lot & $\mathrm{C}$ & S (\%) & NS (\%) & AS (\%) & DS (\%) \\
\hline \multirow{3}{*}{1} & 1 & 17 & 36 & 58 & 6 & \multirow{3}{*}{6} & 1 & 12 & 40 & 60 & 0 \\
\hline & 2 & 27 & 61 & 39 & 0 & & 2 & 27 & 48 & 50 & 2 \\
\hline & 3 & 56 & 66 & 34 & 0 & & 3 & 61 & 52 & 46 & 2 \\
\hline \multirow{3}{*}{2} & 1 & 15 & 7 & 8 & 0 & \multirow{3}{*}{7} & 1 & 12 & 70 & 30 & 0 \\
\hline & 2 & 21 & 10 & 11 & 0 & & 2 & 24 & 67 & 27 & 6 \\
\hline & 3 & 64 & 33 & 30 & 1 & & 3 & 64 & 58 & 38 & 4 \\
\hline \multirow{3}{*}{3} & 1 & 23 & 42 & 53 & 5 & \multirow{3}{*}{8} & 1 & 12 & 44 & 20 & 36 \\
\hline & 2 & 28 & 45 & 55 & 0 & & 2 & 22 & 37 & 48 & 15 \\
\hline & 3 & 49 & 48 & 52 & 0 & & 3 & 66 & 43 & 52 & 5 \\
\hline \multirow{3}{*}{4} & 1 & 15 & 50 & 47 & 3 & \multirow{3}{*}{9} & 1 & 11 & 61 & 35 & 4 \\
\hline & 2 & 25 & 54 & 44 & 2 & & 2 & 18 & 69 & 31 & 0 \\
\hline & 3 & 60 & 55 & 44 & 1 & & 3 & 71 & 72 & 25 & 4 \\
\hline \multirow{3}{*}{5} & 1 & 9 & 61 & 39 & 0 & \multirow{3}{*}{10} & 1 & 26 & 12 & 9 & 5 \\
\hline & 2 & 22 & 40 & 53 & 7 & & 2 & 29 & 13 & 10 & 6 \\
\hline & 3 & 69 & 52 & 46 & 2 & & 3 & 45 & 19 & 24 & 2 \\
\hline
\end{tabular}


In some cases, such as in lot 5 , for example, seed germination was lower even with a larger area was filled with the embryo and endosperm (category 2 compared to 1 and category 3 compared to 2) (Table 2). It is worth pointing out that the differences in seed area occupied by the embryo and endosperm between the categories were small and that the seed structures were undamaged. Therefore, for this reason, the physiological potential was responsible for their germination performance, considering that seeds with a greater filled area (category 3) gave rise to both normal and abnormal seedlings (Figure 4). Similar results were observed by Gagliardi and Marcos-Filho (2011) for bell pepper seeds, when even the undamaged seeds in some lots with an internal area completely filled by the embryo and endosperm gave rise to abnormal seedlings and non-germinated seeds.

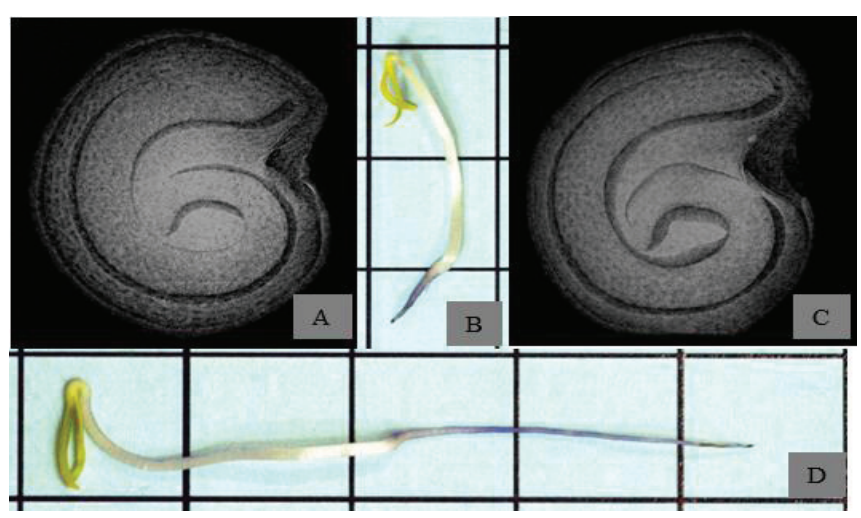

Figure 4. Eggplant seeds, Embu cultivar, represented by lot 5 , category 3 (A and $\mathrm{C}$ ) and the respective abnormal (B) and normal (D) seedlings.

An analysis of the germination results showed that the percentage of dead seeds was small for most of the lots compared to the percentage of abnormal seedlings (Table 2). This higher percentage of abnormal seedlings occurred for most lots independently of the seed area occupied by the embryo and endosperm, that is, the seed physiological potential was more important for this aspect and only the seeds of lot 1 with a greater area occupied by the embryo and endosperm (category 3 ) showed higher germination. For dead seeds, only in lots 8 and 10 was there a greater percentage in categories 1 and 2 , those with a smaller area occupied by embryonic seed tissues; therefore, in most cases, the physiological potential was responsible for this result and not the seed morphology.

Downie et al. (1999) verified that considerable differences in the physiology of tomato seeds, such as the activity of the cell cycle and the micropylar energy of the endosperm, were present in seeds with the same area occupied by the embryo and endosperm and the presence of the free space cannot be considered isolated to predict seed behavior and germination.

Studying the relationship between the seed morphology of castor bean and germination from individual seedlings, Gomes Junior (2010) observed that seeds with a larger embryonic area did not necessarily produce taller seedlings, that is, the relationship between seed morphology and physiological potential was not always positive. Besides the seed morphology, other factors act in seedling germination and development, including the mobilization of reserves, which is one of the first phases of germination and is essential for the embryo to complete seedling establishment (Nonogaki, 2006).

The analysis of the X-rays allowed the visualization of the component parts of the seeds, and, consequently, the study of internal morphology, while the Image Pro Plus ${ }^{\circledR}$ software permitted the measurement of the seed area and the internal cavity occupied with the tissues. These results are important because computerized methods, using high velocity image capture and data processing, are the most advanced ones for a high level of precision in seed quality analyses (Dell’Áquila, 2009).

An analysis of the images of eggplant seedlings (Figure 5) showed that the main abnormality found was a shortening and thickening of the roots. The reduction in seedling growth is a consequence of seed deterioration. Mohammadi et al. (2011) observed that the growth of seedlings from soybean seeds and the mobilization of reserves decreased with increasing deterioration, attributing this to a reduction in the amount of reserves mobilized and not in the efficiency of the use of the reserves. Cytogenetic analyses have shown that the decrease in seed viability during aging is correlated with the increase in the frequency of aberrations in meristem cells of the seedling roots (Pijlen et al., 1995). 


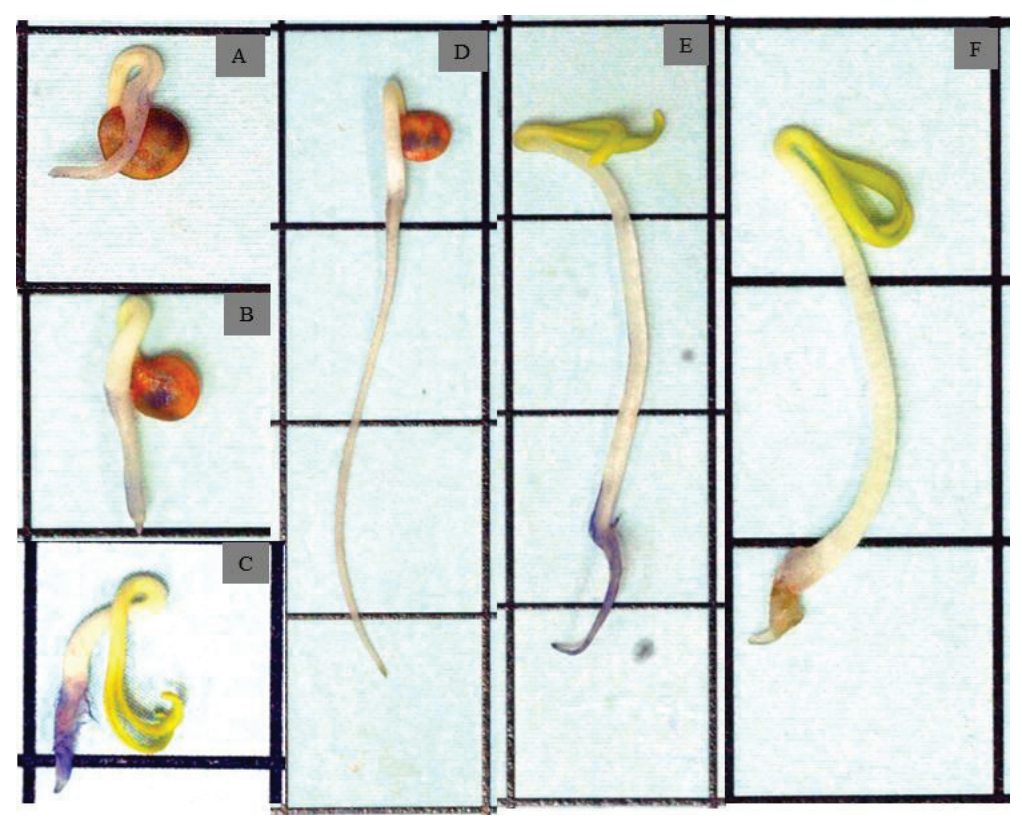

Figure 5. Types of seedling abnormality in eggplant observed in the germination test with problems in the roots (A, C, D, $\mathrm{E}$ and $\mathrm{F})$ and the aerial part (B, E, F).

\section{Conclusion}

The analysis of X-rays permits the visualization of the component parts of eggplant seeds, permitting the study of the relationship between the internal morphology and germination. The presence of a larger area occupied by the embryo and endosperm did not favor germination. Mechanical damage or the presence of deteriorated tissues in seeds can adversely affect germination.

\section{Acknowledgements}

The Fundação de Amparo à Pesquisa of São Paulo State (FAPESP) for the Ph.D. scholarship granted to the first author and for financing this study, Process No. 2009/51689-3.

\section{References}

AMARAL, J.B.; MARTINS, L. FORTI, V.A.; CICERO, S.M.; MARCOSFILHO, J. Teste de raios X para avaliação do potencial fisiológico de sementes de ipê roxo. Revista Brasileira de Sementes, v.33, n.4, p.60607, 2011. http://www.scielo.br/scielo.php?script=sci_pdf\&pid=s0101$31222011000400001 \& \operatorname{lng}=\mathrm{en} \& \mathrm{nrm}=\mathrm{iso} \& \operatorname{tng}=\mathrm{pt}$

BRASIL. Ministério da Agricultura, Pecuária e Abastecimento. Regras para análise de sementes. Ministério da Agricultura, Pecuária e Abastecimento. Secretaria de Defesa Agropecuária. Brasília, DF: MAPA/ACS, 2009. 395p. http://www.agricultura.gov.br/arq_editor/file/laborat $\%$ c3\%b3rio/sementes/ regras $\% 20$ para $\% 20$ analise $\% 20 \mathrm{de} \% 20$ sementes.pdf

CICERO, S.M.; BANZATTO-JUNIOR, H.L. Avaliação do relacionamento entre danos mecânicos e vigor, em sementes de milho, por meio da análise de imagens. Revista Brasileira de Sementes, v.25, n.1, p.2936, 2003. http://www.scielo.br/scielo.php?script=sci_pdf\&pid=s0101$31222003000100006 \& \operatorname{lng}=\mathrm{en} \& \mathrm{nrm}=\mathrm{iso} \& \mathrm{tlng}=\mathrm{pt}$

DELL'AQUILA, A. Pepper seed germination assessed by combined X-radiography and computer-aided imaging analysis. Biologia Plantarum, v.51, p.777-781, 2007. http://www.springerlink.com/content/ k615279r5854188j/fulltext.pdf

DELL'AQUILA, A. Digital imaging information technology applied to seed germination testing. A review. Agronomy for Sustainable Development, v.29, p.213-221, 2009. http://www.agronomy-journal.org/index.php?option=com article\&access $=$ doi\&doi=10.1051/agro:2008039\&Itemid $=129$

DOWNIE, B.; GURUSINGHE, S.; BRADFORD, K.J. Internal anatomy of individual tomato seeds: relationship to abscisic acid and germination physiology. Seed Science Research, v.9, p.117-128, 1999. http://journals. cambridge.org/download.php?file $=\% 2$ fssr $\% 2$ fssr9_02\%2fs0960258599 000136a.pdf\&code $=$ c6ce1f5b56410c7b3f42f347c677729f

GAGLIARDI, B.; MARCOS-FILHO, J. Relationship between germination and bell pepper seed structure assessed by the X-ray test. Scientia Agricola, v.68, n.4, p.411-416, 2011. http://www.scielo.br/pdf/sa/v68n4/v68n4a04.pdf

GOMES JUNIOR, F.G. Aplicação da análise de imagens para avaliação da morfologia interna de sementes. Informativo Abrates, v.20, n.3, 2010. http://www.abrates.org.br/wqsementes/downloads/minicursos/minicurso2/ 
francisco_guilhien.pdf

ISTA. International Seed Testing Association. Regras internacionais para análise de sementes. Seed Science and Technology, 2004. 174p.

LIU, Y.; VAN DER BURG, W.J.; AARTSE, J.W.; VAN ZWOL, R.A.; JALINK, H.; BINO, R.J. X-ray studies on changes in embryo and endosperm morphology during priming and imbibition of tomato seeds. Seed Science Research, v.3, n.3, p.171-178, 1993. http://journals. cambridge.org/download.php?file $=\% 2$ fssr $\% 2$ fssr3_03\%2fs0960258500 001756a.pdf\&code $=$ e62ced54773207cf00828a47df480146

MACHADO, C.F.; CICERO, S.M. Aroeira-branca (Lithraea molleoides (Vell.) Engl. Anacardiaceae) seed quality evaluation by the X-ray test. Scientia Agricola, v.60, n.2, p.393-397, 2003. http://www.scielo.br/ scielo.php?script $=$ sci_pdf\&pid=S0103-90162003000200026\&lng=en\& nrm=iso\&tlng=en

MARCOS-FILHO, J.; GOMES JUNIOR, F.G.; BENNETT, M.A.; WELLS, A.A.; STIEVE, S. Using tomato analyzer software to determine embryo size in x-rayed seeds. Revista Brasileira de Sementes, v.32, n.2, p.146153, 2010. http://www.scielo.br/scielo.php?script=sci_pdf\&pid=S0101$31222010000200018 \& \operatorname{lng}=\mathrm{en} \& n r m=$ iso \&tlng=en

MENEZES, N.L.; CICERO, S.M.; VILLELA, F.A.; BORTOLOTTO, R.P. Using $\mathrm{X}$ rays to evaluate fissures in rice seeds dried artificially. Revista Brasileira de Sementes, v.34, n.1, p.70-77, 2012. http://www. scielo.br/pdf/rbs/v34n1/a09v34n1.pdf
MOHAMMADI; H.; SOLTANI, A.; SADEGHIPOUR, H.R.; ZEINALI, E. Effects of seed aging on subsequent seed reserve utilization and seedling growth in soybean. International Journal of Plant Production, v.5, n.1, p.65-70, 2011. http://www.sid.ir/en/vewssid/j_pdf/124220110106.pdf

NONOGAKI, H. Seed germination - The Biochemical and molecular mechanisms. Breeding Science, v.56, p.93-105, 2006. http://www.jstage. jst.go.jp/article/jsbbs/56/2/93/_pdf

OLIVEIRA, L.M.; CARVALHO, M.LM.; DAVIDE, A.C. Utilização do teste de raios $\mathrm{X}$ na avaliação da qualidade de sementes de canafístula (Peltophorum dubium (Sprengel) Taubert. Revista Brasileira de Sementes, v.25, n.1, p.116-120, 2003. http://www.scielo.br/scielo.php?script=sci pdf\&pid=S0101-31222003000100018\&lng=en\&nrm=iso\&tlng=pt

PIJLEN, V.J.G.; KRAAK, H.L.; BINO, R.J.; VOS, C.H.R. Effects of ageing and osmopriming on germination characteristics and chromosome aberrations of tomato (Lycopersicon esculentum Mill.) seeds. Seed Science and Technology, v.23, p.823-830, 1995.

SIMAK, M.; GUSTAFSSON, A. X-ray photography and sensitivity in forest three species. Hereditas, v.39, p.458-468, 1953. http://onlinelibrary. wiley.com/doi/10.1111/j.1601-5223.1953.tb03430.x/pdf

VAN DER BURG, W.J.; AARTSE, J.W.; VAN ZWOL, R.A.; JALINK, H.; BINO, F.J. Predicting tomato seedling morphology by X-ray analysis of seeds. Journal of the American Society for Horticultural Science, v.119, p.258-263, 1994. http://journal.ashspublications.org/content/119/2/258.full.pdf +html 